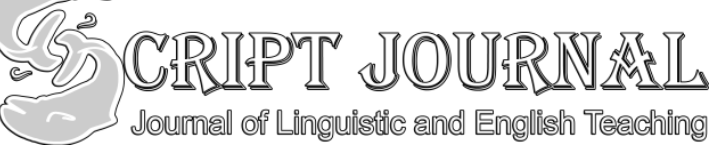

http://jurnal.fkip-uwgm.ac.id/index.php/Script Script Journal: Journal of Linguistic and English Teaching P-ISSN: 2477-1880; E-ISSN: 2502-6623 April 2017, Vol. 2 No. 1

\begin{tabular}{|c|c|c||}
\hline Received: April 2017 & Accepted: April 2017 & Published: April 2017 \\
\hline \hline \multicolumn{2}{|c|}{ Article DOI: http://dx.doi.org/10.24903/sj.v2i1.80 } \\
\hline
\end{tabular}

\title{
Techniques for Teaching Speaking Skill in Widya Gama Mahakam University
}

\author{
Arbain \\ Widya Gama Mahakam University, \\ Samarinda, Indonesia \\ baintigers@gmail.com \\ Dedi Rahman Nur \\ Widya Gama Mahakam University, \\ Samarinda, Indonesia \\ d.blues84@gmail.com
}

\begin{abstract}
Speaking as one of the four skills in English is seen as the most crucial skill to be mastered by English learners. For most people the successes in learning a language can be seen from how far the student can speak and communicate in the language learn. But in fact, speaking is often neglected in the classroom. The objective of this research is to investigate techniques in teaching speaking skill in second semester of primary school department of Widya Gama Mahakam University. This study employs the qualitative design by which the researcher intends to discover and understand techniques of teaching speaking used by the lecture in its natural setting. The subject of this research was second semester students of primary school department. This study reveals four techniques employed by the lecturer in teaching speaking skill, i.e. show-and-tell, presentation, drama making, and question and answer. Show-and-tell and presentation technique are two types of performance talk which were used more often by the lecturer than the two other techniques (i.e. drama making and question and answer).
\end{abstract}

Keywords: techniques, teaching, speaking skill 


\section{INTRODUCTION}

As stated by Lazaraton (2001cited in Celce- Murcia, 2001:103) perhaps the most difficult aspect of spoken English is that it is almost always accomplished via interaction with at least one other speaker. This means that a variety of demands are in place at once: monitoring and understanding the other speakers, thinking about one's own contribution, producing that contribution, monitoring its effect, and so on. To cope with the challenges of teaching speaking, the language lecturer is required to be able to create and employ certain techniques in order to achieve the goal of language learning and teaching for speaking skill. By this, it means that the lecturer plays an important role in determining what technique can best encourage students' participation in the learning speaking process, because studying English without speaking English is useless. Through speaking one can express their minds, ideas and thought freely and spontaneously. To most people, mastering speaking is the single most important aspect in learning second language. This is supported by Celce-Murcia, 1979 who mentions that lecturer needs to know the strategies and two exercises to ensure that each is getting a relevant practice in speaking English in order to develop his fluency and confidence. In line with that, Rahmawati (2008), (Nur, 2016) proposes that lecturer, particularly in speaking instruction, is always expected to provide an engaging-students techniques to make them able to explore their experiences and idea in oral way.

The objective of this research is to investigate techniques in teaching speaking skill in second semester of primary school department of Widya Gama Mahakam University. In other words, the significance of the study is to reveal lecturer's technique in teaching speaking. Through This research, the lecturer will be able to increase teaching speaking skills better, to know the causes of students' problem in English speaking activity. There are many techniques which can be used for teaching speaking. In this section, those techniques are classified based on the functions of speaking. The researcher will use; show and tell, presentation, drama and question and answer

\section{METHODOLOGY}

This study employs the qualitative design by which the researcher intends "to discover and understand a phenomenon" (Arbain, 2017), (Nur, 2017)of techniques of teaching speaking used by the lecturer "in its natural setting” (Denzin \& Lincoln, 1994: 2). In this research descriptive qualitative research, the subjects are direct observation, questionnaire sheets for the entire students of primary school department of Widya Gama Mahakam University which 20 students in the class and a personal questionnaire to the lecturer. This 
research employed classroom observation. This technique is intended to find the answer of the first research question posed in this study. The observation aims to discover the process of teaching speaking by the observed lecturer. The data from observation in form of field note which were used to identify the technique in teaching speaking were classified based on types of technique used by the lecturer.

\section{FINDINGS}

The data from classroom observation are used to identify the lecturer's performance during speaking classes. In this section, the data which show the lecturer's technique (or findings) will be described and analyzed based on three things. First, each technique will be analyzed whether it addresses one of speaking functions, i.e. interpersonal, transactional, and performance (Brown and Yule, 1983 in Richard, 2005), (Arbain, 2016). Second, each technique will be analyzed whether it involves the aspects of cognitive (i.e. knowledge of extra linguistic and linguistic), psycho motoric (skill), and affective (motivation). Third, it will be analyzed whether it has met the principles of the speaking teaching, proposed by Brown (2007).

In general, data from observation show that the techniques used by the lecturer in teaching speaking form the student centered interaction in which the students are dominant in classroom. This is in line with what Brown (2001) mention as follows: "Learner-centered approach helps to give students a sense of 'ownership' of their learning and thereby adds to their intrinsic motivation". On the other hands, the lecturer seems to be as controlled and facilitator as suggested by Harmer (2007). As mentioned previously, this study identifies four techniques used by the lecturer in teaching speaking skill, involving show-and-tell, presentation, drama, and question-and-answer; each will be discussed in the subsequent sections.

\section{Show and tell}

In using this technique the lecturer required a pair of students took turn to show and tell their task preparation. Moreover, this technique was identified in observation one and two. The data below represent show and tell technique:

- S3: I want to tell about hand phone Samsung. This hand phone has 5 megapixel camera, Bluetooth, MP3 player with new hands-free ... night mode camera.

- S4: This hand phone has beautiful color. If you attract to buy it, you can buy with no high price ... you just pay 1 million rupiah. That's ...Thanks for your attention 
The lecturer invited a couple of students to come to the front of classroom to describe an object. Two students walked to the front. One of them showed a product (shoes), while another one attempted to describe it using English. Since the speaker spoke in low voice, the lecturer asked him/her to raise his/her voice. During the presentation, the lecturer found that the speaker pronounced the word "very" inaccurately. The lecturer asked all students to practice pronouncing the word "very" in "very famous", "very expensive", and "very comfortable". This way indicates a type of classroom performance that is imitative $(H$. D. Brown, 2001) and drilling (Thornbury, 2004, Brown, 2001). According to Brown drills offer students an opportunity to listen and to orally repeat certain string of language that may pose some linguistic difficulty either phonological or grammatical.

\section{Observation 1}

Presenter: OK everybody, we show you our product, you can see the shoes. These shoes are very good. The shoes made of leather and the colors are black and brown. I think this is very famous. We have various numbers, the size.

Lecturer: Excuse me, Could you speak louder, please.

Presenter: Yes, sir. This product is very famous and you can buy in Lembuswana mall or Robinson. It is comfortable you may try (another presenter gives the shoe to a student who sitting in the back).

Lecturer: Please repeat 'very famous', 'very expensive', 'very comfortable', Does anyone love the shoes? Well, then next student please!

After the speaker had completely described the product, the lecturer invited the rest of the class to ask questions. This can be seen in the lecturer's expression below:

L: Is there any question about the product? Is there any question Ira?

The expression indicates that the lecturer provided opportunities to the students to practice among their friends in the classroom in order that they freely expressed their ideas. The purpose of the activity is to get the student to train their ability to use English. Thus, the communicative competence (Canale and Swain) was achievable. Related to the show and tell technique, the lecturer had the students present their task in front of the class. In this case, after the first student had finished showing and telling his product, another one came and described another product (jacket). One of them described it in English, while another showed it to the rest of the class. 
The speaker asked the lecturer the word "harga" (Indonesian word for "prize") in English; "harga what sir?" The lecturer mentioned the word "price". Another question asked by the speaker: "sir, what do you say this (showing a cap)? The lecturer mentioned that it was a cap. At the end, the lecturer reminded the students that pronunciation and intonation is important in speaking. The lecturer asked to check their dictionary to find how particular words (color, comfort, comfortable) which were found during presentation session were pronounced. This means that the lecturer directly encouraged and assisted the students in pronouncing the certain cords. Whereas, it is found that fluent spoken is not simply a function of wide-ranging knowledge of grammar, an extensive vocabulary and native-like pronunciation.

In observation two, students showed and spoke about a pair of shoes that concerning the color, size, and number. The lecturer sometimes interrupted the presentation to give corrective feedback regarding the pronunciation and the meaning of certain words. He also gave some examples of certain expressions which were asked by the students.

\section{Observation 2}

Lecturer: Ok, as I told you everybody should deliver your topic in front of the class. Sekarang ini udah hampir selesai semua kan? sama saya kan? Sudah selesai semua, tapi but yang harus kalian perbaiki, all of you, first is your vocabulary. Ok tolong perbaiki lagi your vocabulary. You can ignore your grammar or even your pronunciation. Kalian boleh mengabaikan yang 2 ini,itu ga jadi masalah, tapi yang harus kalian tambah adalah your vocabulary. Ok tolong diperbanyak your vocabulary kalian dengan cara membaca. Ok reading the text. Kalo kamu mau lebih mudah caranya dengan baca. Reading the text. Itulah makanya saya kasih tugas yang buat baca short story kan? Tolong baca short storynya dan make your own comment and submit it tomorrow. Yang belum mengumpulkan tugas siapa? In this class there some more, oh yeah, your turn now.

The lecturer invited a student to introduce a product in front of the class. The student introduced a product (bag). During the presentation, he/she asked the lecturer for help about the word "palsu (synthetic)": "palsu apa ya? (What's "palsu" in English?)". The lecturer mentioned that it was "synthetic". During the presentation, the lecturer provided corrective feedback "it's comfort...? Comfortable". The lecturer also prompted the speaker to explain more about the product by asking "what is the usefulness of your product?". 
The presenter asked the lecturer for help about how to say particular words in English: "what is bentuknya and lembut in English?" (what are "shape" and "soft" in English). The lecturer answered that it was shape and soft. After the speaker had finished introducing his/her product, the lecturer invited the rest of class to ask questions to the presenter. One of the question was "where we can buy the product?". The lecturer asked the student to repeat his/her question "repeat, if everybody wants to buy the product, where will they go? Where can they buy?". Another question was asked by another student "what is the difference the designed product and the original one?". The presenter answered "soft and... what is tali (rope) in English?”

The lecturer answered that it was "rope". The presenter continued "the rope is strong". The session had completed. The lecturer let the speaker go back to his/her seat and admired him/her: "I do appreciate you, even though you did not prepare, at least, you are brave to stand here". The lecturer then explained how to describe a product based on its shape, its color, and its price. The lecturer explained that vocabulary can be improved through reading, and that grammar and pronunciation may be ignored in speaking.

\section{Presentation}

Presentation deals with the individual students give a talk on a given topic or person. In order for this to work for the individual (and for the rest of the class) (Harmer, 2007). In this case, the time must be given for the students to gather information and structure it accordingly. The students listening to presentation must be given some kinds of listening task too including, perhaps giving feedback. Presentation is one of the four successful activities with higher-level students in getting students to practice 'speaking as a skill' (2007:129). This corresponds to prepare talks (Harmer, 2007) where a student (or students) makes a presentation on a topic of their own choice. It means that the lecturer acquired the students to present their presentation in front of the classroom. This can be seen in the following extract that shows the presentation technique.

T: Okay. Thank you very much to God... and before we start our presentation, as usual I'd like to remind you next month at 8 March you start your final test. So, we still get at least a month. So, I'll remind you again about your movie. So, how many of you who hasn't bring movie to me? 
S7: S7 and my friend S8. We will talk about types of lecturer. In our opinion, these are three types of lecturer, working- lecturer, teaching- lecturer, educating- lecturer. First, working lecturer, they become a lecturer just only for the status of the working. Second, teaching- lecturer, they only give students test, exam, subject, they don't really care, understand.

Third, educating lecturer, that's the lecturer who not only give us subject or knowledge from the book ... but give us bigger knowledge from whenever it is ... and understand many things, open-minded. Oke lanjutkan.

S8: Now, some of lecturer only teach their student without taking care of the students are understand or not the subject, but remind the student to be able to do the exam. Positive thing of this type of lecturer is make student study more harder than before, but the negative thing is if the student are lazy, they will not learn anything.

However, observation three, four and ten were related to presentation technique. Observation two shows that the students were asked to present an article taken from newspaper or magazine. At the time of observation, two students presented an article about the issue of Drag Race in front of class.

\section{Observation 3}

Lecturer: Good morning, we still focus on presentation. Who is the presenter today

Presenter: Yes, sir. Our topic is Drag Race

Lecturer: What do you think of the issue, Drag Race?

Lecturer: Do you agree? Please give your opinion about the issue.

The Lecturer reminded the students about their previous topic of presentation. The Lecturer asked a pair of students to talk about an issue of "drag race". Two students came and presented the issue in front of the class and delivered some positive and negative aspect of "drag race". During the presentation, the Lecturer helped the students keep speaking by providing some guided questions. The Lecturer also corrected speaker's error in the use of preposition to and for. After the speaker had completed the presentation, the Lecturer asked the rest of students to ask questions to the speaker. Three students took turn asking and commenting: "Is there any legal activity? I mean the local government gives permission to do racing?, "Is there any group available for girls?", and "I think the local government should provide special place for the drag racer". The discussion over the issue began, after the speaker answer the first and the second question. Several students were involved in the discussion of giving opinion. 
In the presentation the two students took turns to elaborate the positive and negative effect of Drag race. They also stated their opinions about the Drag Race issue. At the end of the presentation, other students were given time to raise questions, comments, or other contrast opinions in accordance with the presented issue. Here the Lecturer frequently encouraged the students to give their questions, comments or opinions.

In observation seven, the students were given an assignment to do presentation. At the time of observation, one group consisting of four students presented the issue of national exam. The group firstly, delivered their opinions regarding their agreements and disagreements toward the national examination issue.

\section{Observation 4}

Lecturer: Would you like coming front?

Student: The positive and negative effects of National Exam

Lecturer: Apa itu dibacanya lefek/ or /ifek/(correct the student pronunciation) Please present your burning issue, the National Exam Let's see do you agree or disagree? Raise your fingeris there any question? Eva Yulianti give your opinion (Provide the opportunity to have question to the presenter)

The Lecturer called students' name to deliver presentation. Two students came and began presented an issue of National Examination (NE). The presenter read a script about NE in front of the students. During the presentation, the Lecturer corrected the speaker pronunciation "apa itu dibacanya /effek/ atau /ifek/?" (how can you pronounce it, /efek/ or /ifek/?). After the presentation had completed, the Lecturer invited the class to give comment on the issue that had been presented.

Having presented their opinions, the presenting group opened question- comment sessions to other students on the purpose of gaining comments or questions related to the issue of national examination. At the end of presentation, the Lecturer clarified and concluded the essence of the presentation by re- explaining the basic reason of the importance of national examination in the perspective of Indonesian education system.

\section{Drama}

This technique or activity refers to the making of conversation between two or more students off the class. In this activity, students play a role, such as; a doctor and a patient, a lecturer and a student, a passenger and a driver and so on. This technique is quite similar with role a play; but it necessarily takes much longer time (Byrne, 1994, Parkinson \& Thomas, 2000 and Thornbury, 2005). In this activity, the students were asked to record their conversation in 
like a drama. The lecturer provided time for the preparation until all groups were ready to submit. The lecturer provided the comment and feedback after the recording was submitted.

In observation eleven, twelve, and thirteen, students were involved in consultative class. Here the lecturer conducted the teaching-learning process to prepare the students for movie project. In observation eleven and twelve, for instance, students were trained to pronounce certain expressions which were going to be used in the dialogue of movie script.

The lecturer trained the students to have appropriate intonation of such expressions. Meanwhile, in observation twelve, one of the students' movies was watched. Here the lecturer gave several feedback on the students' pronunciation and mimicry in playing certain role in the movie.

\section{Observation 5}

Lecturer: What about your task, making movie? In making the movie you have to pay attention on the intonation. The intonation in speaking English is really important. For example, 'watch out' means angry and Watch out! Be careful! Next, the facial expression such as smile. You have to know that I'd give some point of your movie such as intonation, expression and pronunciation ( Give more explanation about making drama).

The lecturer asked the students whether they had finished the project of making a movie: "What about your task, making a movie?" The lecturer then gave explanation of English intonation. Besides, the lecturer explained the aspect of culture, facial expression and gesture, and pronunciation. The lecturer also alerted the students about grammar, but did not explain it.

In observation twelve, the lecturer gave feedback to the students work (movie) which had been submitted. The lecturer reinforced the students by saying that he appreciated the students' work. Besides, the lecturer wanted to know whether the students could share their problem during the process of making drama.

\section{Observation 6}

Lecturer: Good morning, I'm happy of watching your movie. It's clear sound. I mean the voice was clear with nice conversation and good acting. However, in doing rama you also have made a movie, created your own script and edited. (He appreciated the students' movie task). What about the other group? Do have any difficulties?

Student: It's hard but we can practice

Student: I got difficulties in mimic and expression

Lecturer: (Show a model how to act) Now I want Catty and Rara practice your dialog 
The lecturer commented on the students' assignment of drama making. The lecturer stated that he appreciated the students' drama in terms of the sound, the acting, and the conversation. The lecturer then asked the students about their works; whether they had any difficulty through the process of making it. A student commented "It's hard but we can practice". Another student stated "I got difficulties in mimic and expression. The lecturer modeled how to act in front of a camera and asked two students practicing acting.

In observation thirteen, the lecturer asked groups of student who had not submitted their assignments (movie/drama). The lecturer asked why they had not yet submitted them. The students gave some reasons related to the camera which was unavailable, and the member of the group who were not co-operative.

\section{Question and answer}

Question and answer is also found as a technique in teaching speaking. This is supported by Richards \& Lockhart (1991) as follows: questioning is one of the most common techniques used by lecturer. In some classroom over half of class time is taken up with question-and answer exchanges (Borg \& Gall, 1984). However, the observation fourteen and fifteen one which were firstly considered to be involved in "question and answer" technique were found irrelevant since there was no speaking activities found in these two observations. In observation fourteen, question and answer happened among the students after the lecturer asked them to work in group to discuss a picture found in the learning task. The lecturer prompted the students to speak by addressing some questions.

\section{Observation 7}

Lecturer: Checking the Ss attendance. Do you have the book? (while walking around the room) You have to compare, and discuss. In your opinion what do you think of the picture one? What the man want to do here? So, what do you think, Is he good with the $\operatorname{dog}$ ?

Students: No, because he... (looking at the picture on the textbook)

Lecturer: Wick and greedy what do you mean of these? Try to guest! The Pets, What the meaning of pets? Please, read p 17. Who likes reading text? "unfortunately what is the meaning of unfortunately and fortunately?

(Ask the Ss to write a summary of the story, the present orally in front of the class).

In observations three "question and answer technique" was carried out based on the learning task in the handouts as the main source or material of learning. Students' engagements in the activities were colored by asking and answering the questions taken from their textbooks. 
In observation fifteen, question-and-answer was employed in the beginning of the lesson. The topic that the lecturer highlighted was a phenomenon in the class where many students like staying out of the class.

\section{Observation 8}

Lecturer: Why do students stand out off class?

Students: (present their opinion about the topic chosen) Lecturer: Why the students like going out? Leaving the class? How about if your best friend do the same way

Student: I will give him advice

Lecturer: Would you tell the lecturer? Student: No

Lecturer: Why... What is friendship for you...? Lie together, I'm happy; you are happy, you are sad I'm happy

Student: No... brrr....walk out during the lesson activity

Lecturer: What is best fried for you? Student: When they got nilai buruk... (prompts when somebody got bad score; correct the student's vocabulary)

Lecturer: There are some Faculty regulations. You know sanction: you are not allowed to entering a class.

The lecturer began the lesson by asking question to students. The lecturer asked students "why do students stand out of class?". Students were silent. The lecturer asked again "Why the students like going out? Leave the class?" How about if your best friend do the same way?". A student replied "I give him advice".

\section{DISCUSSION}

In general, data from observation show that the techniques used by the lecturer in teaching speaking form the student centered interaction in which the students are dominant in classroom. As mentioned previously, this study identifies four techniques used by the lecturer in teaching speaking skill, involving show-and-tell, presentation, drama, and question-andanswer; each will be discussed in the subsequent sections.

In summary, from the responses given by the students to the techniques used by their teacher to teach them speaking, it can be inferred that those techniques can motivate students to learn English and facilitate them to speak. These responses were shown by the table below in which the positive attitudes were ranged from $85 \%$ to $100 \%$. 


\section{CONCLUSION}

This study reveals four techniques employed by the lecturer in teaching speaking skill, i.e. show-and-tell, presentation, drama making, and question and answer. Showand-tell and presentation technique are two types of performance talk which were used more often by the lecturer than the two other techniques (i.e. drama making and question and answer). Within all the four techniques, this study identifies that aspects of knowledge in speaking (i.e. extra linguistic and linguistic) receive little attention by the lecturer, the whereas the largest portion of the speaking activities was filled with uncontrolled practice which encourages students' speaking involvement and fluency. The data obtained also seem that the teacher did a lot of speaking after the students took their turn performed the task given. 


\section{BIBLIOGRAPHY}

Allwright, D., \& Bailey, K. (2000). Focus on the language classroom (1st ed.). Cambridge: Cambridge University Press.

Anderson, K., Lynch, T., \& MacIean, J. (2004). Study speaking (1st ed.). Cambridge [u.a.]: Cambridge Univ. Press.

Arbain, A. (2016). Critical Discourse Analysis of Eminem ' s “ Love the Way You Lie Part II ." Script Journal, 1(1), 1-10. https://doi.org/10.24903/sj.v1i1.19.g8

Arbain, A. (2017). Derivation in Headline Articles of the Jakarta Post Newspaper. IJOLTL, 2, 23-30. Retrieved from http://ijoltl.pusatbahasa.or.id/index.php/ijoltl/article/view/230

Brown, H. (2010). Language assessment (1st ed.). White Plains, NY: Pearson Education.

Carter, R., \& Nunan, D. (2001). The Cambridge guide to teaching English to speakers of other languages (1st ed.). Cambridge, England: Cambridge University Press.

Christie, F. Language education in the primary years (1st ed.).

Creswell, J. Educational research (1st ed.).

Eggen, P., Kauchak, D., \& Harder, R. (1979). Strategies for teachers (1st ed.). Englewood Cliffs, N.J.: Prentice-Hall.

Lindfors, J., \& Townsend, J. (1999). Teaching language arts (1st ed.). Urbana, Ill.: National Council of Teachers of English.

Nur, D. R. (2016). An Analysis of Derivational Affixes in Commencement Speech. Script Journal, 1(1), 25-35. https://doi.org/10.24903/sj.v1i1.18

Nur, D. R. (2017). An Analysis of the Feminist Characters in Kate Chopin's "The Awakening." Journal of English Educators Society, 2(April), 1-20. https://doi.org/10.21070/jees.v2i1.687

Ortega, L. (2015). Understanding second language acquisition (1st ed.). [Place of publication not identified]: Routledge.

Spector, J. (2014). Handbook of research on educational communications and technology (1st ed.). New York, N.Y.: Springer. 